\title{
Impact of Abnormal Audit Fee on Audit Opinion
}

\author{
Louis Bernardus Dupa Sangkrista ${ }^{1}$, Fitriany $^{1 *}$ \\ ${ }^{1}$ Faculty of Economics, Universitas Indonesia, Depok, 16424, Indonesia \\ *fitrianyamarullah@gmail.com
}

\begin{abstract}
The objectives of this research are to investigate whether abnormal audit fees affect the probability of audit opinion deteriorating, and whether abnormal audit fees influence the probability of receiving unqualified auditing opinions. Abnormal audit fees comprise the difference between the actual audit fee paid to the auditor and the expected, normal fee that should have been charged for the audit engagement effort. An ordered logit regression technique was used. The study shows that an increase in abnormal auditing fees increases the probability of a better audit opinion given by the auditor. As a result, a degree of opinion shopping does occur in Indonesia. Furthermore, this study also finds that increases in abnormal audit fees also increase the probability of companies obtaining unqualified audit opinions. This shows that abnormal audit fees influence the audit opinion via opinion shopping, increasing auditors' dependence on their clients and decreasing the independence of the auditor. This research provides advice for regulators to encourage mandatory disclosure on auditing fees. Based on available data, it is evident that companies engage in the practice of opinion shopping, in order to maintain or gain a better opinion. Audit fees that are not disclosed allow companies to take these actions more freely, without being controlled by stakeholders. Opinion shopping practices are harmful for capital market conditions because they erode the trust of stakeholders around assurance services.
\end{abstract}

Keywords: Abnormal Audit Fee; Audit Opinion; Opinion Shopping; Audit Fee.

\section{INTRODUCTION}

Opinion shopping comprises efforts made by management to influence or even to manipulate the auditor's decision, so as to give a more favorable audit opinion ${ }^{1}$. It is pertinent to investigate whether a company can influence its audit opinion by offering higher audit fees. The relationship between the audit fee and the formation of audit opinion has been examined by Chen et al. ${ }^{2}$. It was found by the authors that among companies that received a qualified audit opinion, the high level of abnormal audit fee increases the probability of an improved audit opinion. Fang and Hong also find that abnormal audit fees can lead to a better audit opinion ${ }^{3}$. Xie et al. find that high abnormal audit fees are associated with a higher chance of audit opinion improvements (or less chance of audit opinion deterioration) among firms with an abnormally high increase in profitability, but not among firms with a normal increase, or decrease, in profitability 1 .

A common method for detecting the presence of opinion shopping is by comparing the audit opinion before and after switching auditor. Chow \& Rice and Krishnan \& Stephens find no evidence that a change of auditor leads to improvement in the audit opinion ${ }^{4,5}$. Meanwhile, Lennox find that companies are more likely to get a qualified opinion over an unqualified opinion after changing auditors ${ }^{6}$. Further research conducted by Wu \& Tan is inconclusive as to the existence of a significant relationship between changes of auditor and improvements in opinion on financial statements ${ }^{7}$. Various studies indicate that there are still no conclusions regarding the effect that changing auditors has on improving opinions in the following year.

An abnormal audit fee is the difference between the actual audit fee paid to auditors and the expectations of a normal audit fee ${ }^{8}$. Actual audit fees consist of normal fees and abnormal fees. Normal fees indicate the cost of auditors' efforts, the cost of the litigation risk, and the normal profits for the auditor (Simunic; Choi et al.) that are contingent on common factors across different clients, such as size, complexity, and client-specific risk ${ }^{9,10}$. Abnormal fees are expressed as a specific auditor-client relationship ${ }^{11}$, and can be seen as a bribe attempt to the auditor.

Fang and Hong find similar results as Chen et al., in that there is a positive correlation between an abnormal audit fee and audit opinion ${ }^{2,3}$. Xie et al. conduct a study on companies listed in China's capital market, with a range of samples ranging from 2002 to 2008, showing that firms with a high improvement in profitability exhibit an abnormal audit fee that is related to increased audit opinion ${ }^{1}$.

The differences between this study and that of Xie et al. lie in the measurement of abnormal audit fees ${ }^{1}$. The present research study uses the model of Choi et al., as it is considered to give more complete variables compared to Xie et al., including the number of business segments, the number of geographic segments, and the ratio of inventories and accounts receivable as a proxy for the complexity of the firm audit ${ }^{1,8}$. Auditor tenure is also included by Choi et al. to control the fee discount at the beginning of the audit. Total assets and the number of employees as a control for the size of the company has a positive relationship with the audit fee ${ }^{8}$. Change of sales and book-to market-value comprises the control over company growth. Companies involved in the public often have a higher requirement for audit services ${ }^{12}$.

The objectives of this research are to investigate whether abnormal audit fees affect the probability of the deterioration of audit opinion, and whether the abnormal audit fee influences the probability of receiving 
unqualified audit opinions. This study only examines the deterioration of audit opinion because we only have a sample that relates to the deterioration of audit opinion, and there is only limited data for improvements in audit opinion. This study also examines marginal effects, to see the effect of each variable on the probability of the formation of opinion. Predicted probabilities testing is also done to see the overall effect of the variables on the probability of the formation of opinion.

\section{LITERATURE REVIEW AND HYPOTHESIS DEVELOPMENT Audit Fees}

Various studies use a range of models to measure normal audit fees. Factors such as the value of assets, the complexity of the audit, the company's leverage, the audit opinion of the previous year, profitability, and the credibility of the auditor, have all been considered ${ }^{9,12-14}$.

Griffin \& Lont find evidence that there is a difference in audit fee after an auditor turnover between dismissal and withdrawal. Niemi reveals that the concentration of company ownership is one of the factors affecting the amount of audit fee ${ }^{16,17}$.

A study by Xie et al. in China finds that the Big Four Auditing Firms' audit fees tend to increase in premium compared to other firms. This is related to the credibility of the auditor, whereby the reputation of the Big Four gives a higher value to the assurance and tends to garner a stronger response from the users of financial statements ${ }^{1}$.

Chen \& Elder state that the audit fee is influenced by the following factors ${ }^{18}$ :

- The level of complexity of the audited company. Multilevel ownership structures, the presence of a conglomeration of businesses, and the complexity of the company's financial accounting system, all increase the difficulty and level of understanding required to deliver the right opinion

- Expertise of the auditor in conducting an audit of financial statements

- The duration or time taken in performing audits of financial statements.

Both Xie et al. and Choi et al. include total assets as a proxy for the size of the company, return on assets, as well as leverage ${ }^{1,8}$. Big Four variables are taken into account as a control over the higher audit fee (premium) obtained. The model used by Choi et al. incorporates a number of business segments, a number of geographic segments, and the ratio of inventories and accounts receivable as a proxy for the complexity of the audit firms ${ }^{8}$. A tenure variable is also taken into account by Choi et al. to control for the fee discount at the time of the initial audit 8,19 .

The model used by Choi et al also includes variables related to the total assets and number of employees at the company. Both are used as a control over the size of the company, which has a positive relationship with firm size. Changes in sales and book-to-market value comprise the control over the speed of growth of the company. Companies involved in equity and debt deals have a higher requirement for audit services ${ }^{1}$.

\section{Opinion Shopping}

A company is said to be involved in opinion shopping when it is trying to influence or even to manipulate the auditor's decision in order to provide a more favorable audit opinion ${ }^{1}$. Such behavior can lead to increased misinformation or asymmetric information between management and investors, due to the decrease in the reliability of the auditor opinion regarding financial statements.

Various empirical studies have tried to gauge this phenomenon. Evidence still shows inconsistent results on this topic. A common method for detecting the presence of opinion shopping is through comparing the audit opinion before and after the change of auditor. Chow and Rice and Krishnan \& Stephens find no evidence that a change of auditor leads to an improvement in the audit opinion ${ }^{4,5}$. Meanwhile Lennox find that companies are more likely to get a qualified opinion compared with an unqualified opinion after changing auditor ${ }^{6}$. Further research conducted by $\mathrm{Wu} \&$ Tan does not show a significant relationship between changes of auditor and improvements in opinion on financial statements? ${ }^{7}$. Various studies indicate that there is still no conclusion that a change of auditor will improve opinions on the next year.

Another method comprises the company seeking to improve its audit opinion by providing an audit fee that is higher than it should be. This is considered as an attempt to buy the auditor's opinion and is included within the notion of opinion shopping. Chen et al. find that there is a significant correlation between an abnormal audit fee and a better opinion on financial statements in subsequent years. This also proves that the auditor's independence can be affected by a higher fee being offered by management ${ }^{2}$.

\section{The Effect of Abnormal Audit Fee on the Probability of Deterioration of Audit Opinion}

The external auditor is an independent party that provides assurance on the fairness of the financial statements that is expressed in the auditor's opinion. There are several types of opinions given by the auditor, from the best opinion (unqualified opinion) to the worst opinion (adverse and disclaimer opinion that indicates that the 
company has a problem with the going concern in their business). One argument asserts that the going concern opinion given by the auditor to the company makes it more difficult to maintain business continuity ${ }^{20}$. The impact of the going concern opinion includes the loss of confidence of investors and banks in the company's performance. This makes it more difficult to acquire financial aid needed to maintain and improve the condition of the company.

The risk of losing confidence from investors encourages the management to try to acquire and maintain an unqualified opinion ${ }^{21}$. Problems arise when a company does not have high quality financial statements to support the unqualified opinion ${ }^{1}$.This means management must find other efforts to obtain/maintain the desired opinion.

Based on previous research, it is assumed that only companies who need to retain the auditor's opinion without a reliable financial statement base will conduct opinion shopping ${ }^{1,20-22}$. Opinion shopping occurs during negotiations, whereby the auditor encourages management to approve the accounting practices conducted by the management with the threat of dismissal ${ }^{22}$. Meanwhile, the high dependence of auditors on auditing fees makes auditors become more liberal. Auditor independence and objectivity can thus be disrupted because of management's efforts to get a better opinion ${ }^{23}$.

Opinion shopping can occur in the form of abnormal audit fee rewards given to the auditor as an incentive to retain unqualified opinion, regardless of actual financial statement conditions. The higher the abnormal audit fee paid to the auditor, the less likely the company will be to experience a decrease in audit opinion. Based on the explanations above, the research hypothesis is:

H1: Abnormal audit fee negatively affects the probability of deterioration of audit opinion.

\section{The Effect of Abnormal Audit Fee on the Probability of a Firm Receiving an Unqualified Opinion}

This examination of the deterioration and improvement of the audit opinion only examines the increase and decrease of opinion, and does not look at the probability of the audit opinion. It is therefore necessary to examine the impact of the abnormal audit fee on the probability of opinion formation. The focus of this hypothesis is around the effect of an abnormal audit fee on the probability of the company obtaining the best opinion (an unqualified audit opinion), with the condition of the various audit opinions given in the previous year. The higher the abnormal audit fee paid to the auditor, the more likely the company will be to receive an unqualified audit opinion, because of a decline in the independence of the auditor and the high level of auditor dependence on the client. Based on the explanation above, the hypothesis of this study is:

H2: Abnormal audit fee has a positive effect on the probability of a firm receiving an unqualified opinion.

\section{RESEARCH METHOD}

Model to test H1:

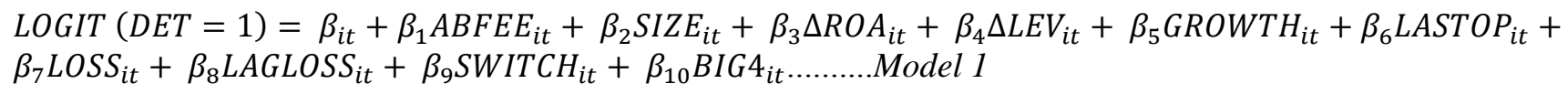

DET: Deterioration; Det $=1$ when Op type ${ }_{\mathrm{t}}<\mathrm{Op} \mathrm{type}_{\mathrm{t}-1}$, and 0 otherwise. ABFEE: Abnormal audit fee, calculated as the residuals of Model (3). SIZE Logarithm of total assets at fiscal year-end. $\triangle \mathrm{ROA}$ : Change in ROA, where ROA is net income divided by total assets at the beginning of the year. $\triangle \mathrm{LEV}$ : Change in leverage, where leverage is total liabilities divided by total assets. GROWTH $\triangle$ Size is the growth rate of total assets. LOSS 1 if net income is negative, and 0 otherwise. LAG LOSS variable of Loss. LASTOP: -1 if the prior period audit opinion is unqualified with explanations, -2 if the prior period audit opinion is qualified with or without explanations. -3 if the prior period audit opinion is negative, or if the auditor refuses to express an opinion. SWITCH 1 if the auditor is different from that in the prior period, and 0 otherwise. BIG4 1 if the auditor is one of the international Big Four, and 0 otherwise.

Model to test $\mathrm{H} 2$ :

$$
\begin{aligned}
& \left.\operatorname{LOGIT}_{\left(O P_{t}\right.}=i\right)=\beta_{i t}+\beta_{1} \text { ABFEE }_{i t}+\beta_{2} \text { SIZE }_{i t}+\beta_{3} \Delta R O A_{i t}+\beta_{4} \Delta L E V_{i t}+\beta_{5} \text { GROWTH }_{i t}+\beta_{6} \text { LASTOP }_{i t}+ \\
& \beta_{7} \text { LOSS }_{i t}+\beta_{8} \text { LASTLOSS }_{i t}+\beta_{9} \text { SWITCH Hit }_{i t}+\beta_{10} \text { BIG }_{i t} \ldots \ldots \ldots \text {......odel } 2
\end{aligned}
$$

OP: Opinion on in year t: 0 unqualified opinion; -1 unqualified opinion with explanatory paragraph; -2 Going Concern Opinion

Abnormal audit fee is calculated according to Choi et al. It is the residual value of this modele:

$$
\begin{aligned}
& A F E E=\beta_{0}+\beta_{1} L N T A+\beta_{2} N B S+\beta_{3} N G S+\beta_{4} I N V R E C+\beta_{5} E M P L O Y+\beta_{6} L O S S L A G+\beta_{7} L E V E+\beta_{8} R O A+ \\
& \beta_{9} L I Q U I D+\beta_{10} B I G 4+\beta_{10} S H O R T \_T E N+\beta_{10} B T M+\beta_{11} C H G S A L E+\varepsilon
\end{aligned}
$$


$A F E E$ = natural $\log$ of actual fees paid to auditors for their financial statement audits (i.e., audit fees) in rupiahs. $L N T A=$ natural log of total assets in thousands of dollars. $N B S=$ natural $\log$ of 1 plus the number of business segments. $N G S=$ natural $\log$ of 1 plus the number of geographic segments. INVREC $=$ inventory and receivables divided by total assets. $E M P L O Y=$ square root of the number of employees. $L O S S L A G=1$ if the firm reported a loss during the prior year and 0 otherwise. $L E V E=$ leverage (total liabilities divided by total assets). $R O A=$ return on assets (income before extraordinary items divided by average total assets). $L I Q U I D=$ current assets divided by current liabilities. BIG4 = 1 if the auditor is one of the Big 4 and 0 otherwise. SHORT_TEN=1 if the auditor is in the first or second year of the audit engagement and 0 otherwise. BTM = book-to-market ratio, winsorized at 0 and 4 . CHGSALE = sales change from the prior year divided by the prior year's beginning total assets.

\section{RESULTS AND DISCUSSION}

The population of this research consists of listed companies in the Indonesia Stock Exchange from 2012 to 2013. The sampling method used is purposive sampling with the criteria that there is information about audit fees. The total number of companies listed on the Indonesia Stock Exchange (IDX) was 449 and 465 in 2012 and 2013, respectively. There are just 126 firm years that comprise of 65 companies in 2012, and 61 companies in the year 2013. The data obtained is limited, because in that year only a few companies disclosed information about the audit fee. In fact, the regulator has requested that the company disclose the audit fee in the financial/annual report, but many companies do not comply, perhaps because there is no sanction for non-disclosure. The data was obtained from IDX page, Eikon, Thomson Reuters, Data Stream, and the Indonesia Capital Market Directory (ICMD), as well as from financial statements published by the company.

Table 1 shows a descriptive statistic of the sample. Variable OP was a dependent variable related to the opinion acquired by the company during t period. The highest score was 0 , which describes a company that has an UQ (Unqualified) opinion. Score -1 was given to a company which had an opinion UQ with an explanatory paragraph. Score -2 was given to a company which had a going concern opinion. Data shows only three companies in Indonesia that had qualified opinions in 2012. These companies were not chosen as a sample because they did not disclose audit fees during that period. Meanwhile, there were no companies that obtained an adverse or disclaimer opinion during 2012. Based on the statistical description of the variable OP, the average was -0.44 , which shows that most of the companies were in the level of 0 to -1 , with several of them in the level of -2 or a company with a going concern opinion.

Table.1. Descriptive Statistic - Model 1

\begin{tabular}{|c|c|c|c|c|c|}
\hline Variabel & Observasi & Iean & $\begin{array}{l}\text { Standar } \\
\text { Deriasi }\end{array}$ & $\begin{array}{c}\text { Nitai } \\
\text { Minimum }\end{array}$ & $\begin{array}{c}\text { Nitai } \\
\text { Maksimum }\end{array}$ \\
\hline$O P$ & 126 & 0.44 & 0.61 & $\therefore$ & 0 \\
\hline DET & 126 & 021 & 0.41 & 0 & 1 \\
\hline ABFEE & 126 & 000 & 0.41 & .122 & 1.12 \\
\hline SIZE & 126 & $12800,000,00000$ & $15,900,000,000,00$ & $145,000,000$ & $70,900,000,000$ \\
\hline $\mathrm{DROA}$ & 126 & .0 .03 & 0.07 & .029 & 0.24 \\
\hline DLET & 126 & 002 & 0.08 & .023 & 0.29 \\
\hline GROIITH & 126 & 0.22 & 0.35 & .0 .19 & 263 \\
\hline LASTOP & 126 & -0.56 & 0.54 & .200 & 0.00 \\
\hline LOSS & 126 & 0.12 & 0.33 & 0 & 1 \\
\hline LAGLOSS & 126 & 0.12 & 0.33 & 0 & 1 \\
\hline SIIIICH & 126 & 0.50 & 0.50 & 0 & 1 \\
\hline BIGA & 126 & 052 & 0.50 & 0 & 1 \\
\hline
\end{tabular}

Table.2. Descriptive Statistic - Model 2

\begin{tabular}{|c|c|c|c|c|}
\hline & \multicolumn{4}{|l|}{ LASTOP } \\
\hline OP & $\begin{array}{c}0: \\
\text { unqualified } \\
\text { opinion }\end{array}$ & $\begin{array}{c}-1: \text { UQ } \\
\text { with } \\
\text { explanatory } \\
\text { parg }\end{array}$ & $\begin{array}{c}-2 \text { : } \\
\text { going } \\
\text { concern }\end{array}$ & TOTAL \\
\hline $\begin{array}{l}0: \quad \text { unqualified } \\
\text { opinion }\end{array}$ & 38 & 39 & 2 & 79 \\
\hline $\begin{array}{l}-1: \text { UQ with } \\
\text { explanatory parg }\end{array}$ & 18 & 20 & 1 & 39 \\
\hline-2 : going concern & 2 & 6 & 0 & 8 \\
\hline TOTAL & 58 & 65 & 3 & 126 \\
\hline
\end{tabular}

Table 3 shows that ABFEE was negatively significant ( $p$-value 0.0815 ) which indicates that the probability of the deterioration of opinion would significantly decrease with the increasing fee of the auditor. This shows the existence of opinion shopping, where a company would spend higher auditor fees to achieve better audit opinions. From this evidence, the first hypothesis was proved.

Table 4 shows that the abnormal audit fee (ABFEE) had p-value 0.0015 which was marginally significant 
at $1 \%$. The coefficient of the abnormal audit fee (ABFEE) was positive, which meant that ABFEE increased the probability of acquiring unqualified audit opinions, which in turn showed that opinion shopping occurred.

\section{CONCLUSION}

This research proved that increasing abnormal audit fees decreases the probability of audit opinions deteriorating. This also indicates that companies provide high abnormal audit fee to maintain or achieve a better audit opinion.

Table.3. Regression Result - Model 1

\begin{tabular}{|l|c|c|c|}
\hline \multicolumn{1}{|c|}{ Variabel } & Ekspektasi Tanda & Koefisien & Signifikansi \\
\hline ABFEE & - & $-0.8713^{*}$ & 0.0815 \\
\hline SIZE & + & 0.2765 & 0.1305 \\
\hline DROA & - & -3.1822 & 0.2855 \\
\hline DLEV & + & $7.6329^{*}$ & 0.0520 \\
\hline GROWTH & - & -0.3222 & 0.3210 \\
\hline LASTOP & + & $2.4274^{* * *}$ & 0.0000 \\
\hline LOSS & + & 0.6340 & 0.2685 \\
\hline LAGLOSS & + & 0.0737 & 0.4755 \\
\hline SWITCH & + & 0.1708 & 0.3830 \\
\hline BIG4 & - & $-0.8841^{*}$ & 0.0520 \\
\hline F-Test & \multicolumn{2}{|c|}{0.01805} & 126 \\
\hline \multicolumn{4}{|r|}{ Dep var: DET }
\end{tabular}

Table 4. Regression Result - Model 2

\begin{tabular}{|l|c|c|c|}
\hline \multicolumn{1}{|c|}{ Variabel } & Ekspektasi Tanda & Koefisien & Signifikansi \\
\hline ABFEE & + & $1.6725^{* * *}$ & 0.0015 \\
\hline SIZE & - & $-0.2746^{* *}$ & 0.0430 \\
\hline DROA & + & $3.2967^{* *}$ & 0.1795 \\
\hline DLEV & - & $-8.5289^{* * *}$ & 0.0065 \\
\hline GROWTH & + & 0.9909 & 0.1055 \\
\hline LASTOP & - & -0.1816 & 0.3265 \\
\hline LOSS & - & -0.4858 & 0.2855 \\
\hline LAGLOSS & - & -0.0567 & 0.4735 \\
\hline SWITCH & - & -0.4250 & 0.1510 \\
\hline BIG4 & + & $0.9582^{* *}$ & 0.0175 \\
\hline F-Test & \multicolumn{2}{|c|}{$\mathrm{n}$} & 126 \\
\hline
\end{tabular}

The research also proved that increases in abnormal audit fees increases the probability of the company obtaining unqualified audit opinions. This shows that there were indications of abnormal audit fees influencing the audit opinion in the form of opinion shopping that increases auditor dependence on their clients.

The limitations of this research relate to limited data. Only a few of Indonesia's listed companies disclosed information about audit fee. Further research might expand this sample. This research also did not consider the impact of industry characteristics on the calculation of abnormal audit fees and the probability model of the audit opinion. The diversity of the industry can influence the risk and complexity of the company, and thus can affect the audit fee. This research also did not consider the characteristics of the industry, because of limitations on the data of audit fees. Further research could divide the sample by industry category.

This study uses an abnormal audit fee model developed by Choi et al. ${ }^{8}$. A measurement of abnormal audit fee has been developed by many researchers. Further research can carry out a similar test by comparing the measurement of various abnormal audit fee models, to ascertain the consistency of the results.

This research did not conduct a separate test between the positive and negative abnormal audit fee because of the limitations of the research data. Further research can conduct separate testing with the aim of seeing the effect of each discount and premium abnormal audit fee on the audit opinion.

This research provides advice for regulators to encourage the mandatory disclosure on audit fee. Based on available data, it is evident that some companies are involved in the practice of opinion shopping, whereby companies seek to maintain or gain a better opinion. Audit fees that were not disclosed allow companies to take these actions more freely, without any control from stakeholders/regulators.

Opinion shopping practices are harmful for the capital market condition because they eliminate the trust of stakeholders regarding assurance services. This happens because the quality of the audit opinion will be lower, owing to its impact on auditor independence. 


\section{REFFERENCES}

[1] Z. Xie, C. Chun, Y. Jianming. Abnormal Audit Fees and Audit Opinion - Further Evidence from China's Capital Market. China Journal of Accounting Research, 3(2010) 51-70.

[2] C. J. P. Chen, X. Su, X. Wu. Abnormal audit fees and the improvement of unfavourable audit opinion. China Accounting and Finance Review, 7(2005) 1-28.

[3] J. X. Fang, J. Q. Hong. Abnormal audit fees and their damage to audit quality. China Accounting Review, 6(2008) 425-442.

[4] C. W. Chow, S. J. Rice. Qualified audit opinions and auditor switching. Accounting Review, 57(2)(1982) 326-335.

[5] J. Krishnan, R. G. Stephens. Evidence on opinion shopping from audit opinion conservatism. Journal of Accounting and Public Policy, 14(3)(1995) 179-201.

[6] C. Lennox. Do companies successfully engage in opinion-shopping? Evidence from the UK. Journal of Accounting and Economics, 29(2000) 321-337.

[7] L. S. Wu, L. Tan. Auditor switch and the improvement of audit opinion. Auditing Research, 2 (2005) 34-40.

[8] J-H. Choi, J-B. Kim, and Y. Zang. Do Abnormally High Audit Fees Impair Audit Quality. A Journal of Practice and Theory, 29(2) (2010) 115-140.

[9] D. A. Simunic. The Pricing of Audit Service: Theory \& Evidence. Journal of Accounting Research, 1(1980).

[10] J-H. Choi, J-B. Kim, Yoonseok Zang. Audit office size, audit quality, and audit pricing. Auditing: A Journal of Practice \& Theory, 29(1)(2010) 73-97.

[11] J. L. Higgs, T. R. Skantz. Audit and non-audit fees and the market's reaction to earnings announcements. Auditing: A Journal of Practice \& Theory, 25(1)(2006) 1-26.

[12] J. Reynolds, D. Deis, J. Francis. Professional service fees and auditor objectivity. Auditing: A Journal of Practice and Theory, 23(1)(2004) 29-52.

[13] J. R. Francis. The effect of audit firm size on audit prices: A study of the Australian market. Journal of accounting and economics, 6(2)(1984) 133-151.

[14] Z-V. Palmrose. The Effect of Nonaudit Services on the Pricing of Audit Services: Further Evidence. Journal of Accounting Research, 24(2)(1986) 405-411.

[15] J. R. Francis, D. J. Stokes. Audit prices, product differentiation, and scale economies: Further evidence from the Australian market. Journal of Accounting Research (1986) 383-393.

[16] P. A. Griffin, D. H. Lont. Audit Fees around Dismissals and Resignations: Additional Evidence. Journal of Contemporary Accounting and Economics, 7(2)(2011) 65-81.

[17] L. Niemi. Audit Effort and Fees Under Concentrated Client Ownership: Evidence From Four International Audit Firms. The International Journal of Accounting, 40(4)(2005) 303-323.

[18] Chen, Yao-Tsung, and Randal J. Elder. "Industry specialization and audit fees: The effect of industry type and market definition." PhD diss., Syracuse University., 2001.

[19] I. Gavious. Alternative Perspectives to Deal with Auditors' Agency Problem. Critical Perspectives on Accounting, 18(4)(2007) 451467.

[20] S. Sankaraguruswamy, K. Raghunandan, S. Whisenant. Factors associated with and long term stock price performance of firms making disclosures of auditor-client frictions, SSRN (2005).

[21] E. Ruiz-Barbadillo, N. Gómez-Aguilar, E. Biedma-López. Long-term audit engagements and opinion shopping: Spanish evidence. Accounting Forum, 30(1)(2006) 61-79.

[22] R. A. Dye. Informationally motivated auditor replacement. Journal of accounting and economics, 14(4)(1991) 347-374

[23] R. Antle, B. Nalebuff. Conservatism and auditor-client negotiations. Journal of Accounting Research, 29(1991) 31-54. 